\title{
Case Study in The Northern Cape (Loopeng Area), South Africa, Confirming Occurrence of a Collapsible Soil Structure in Transported Soils
}

Frederik Daniël Jacobus Stapelberg ( $\sim$ fstapelberg@geoscience.org.za )

Council for Geoscience https://orcid.org/0000-0002-9305-9655

\section{Research Article}

Keywords: Collapsible soil structure, Loopeng, transported soil, empirical properties comparison

Posted Date: November 30th, 2021

DOl: https://doi.org/10.21203/rs.3.rs-317200/v1

License: (c) (1) This work is licensed under a Creative Commons Attribution 4.0 International License.

Read Full License 


\section{$\underline{\underline{\text { Title Page }}}$}

Author:

Title:

Author affiliation:

e-mail:

Author ORCID:

Abstract:

Keywords:

Declarations:
F.D.J. Stapelberg

Case study in the Northern Cape (Loopeng area), South Africa, confirming occurrence of a collapsible soil structure in transported soils

Council for Geoscience, Engineering and Geohazards Unit

fstapelberg@geoscience.org.za

None

Testing was performed on transported soils belonging to recently deposited sandy-silty soil deposits occurring in the Northern Cape Province, South Africa in order to determine the occurrence and order of magnitude of a collapsing sand soil structure. Various empirical geotechnical characteristics including: in situ soil profile structure description, particle grading curve and clay content, soil classification, soil density and void ratio were compared to collapse potential values determined with oedometer testing in order to judge the success with which the empirical characteristics can be utilized to predict the occurrence of a collapsible soil structure.

From the results it is clear that a collapsing sand structure exists in the transported soils and the empirical descriptors mostly correctly indicate the occurrence or the particular soil structure when compared to previous studies on collapsing sands. The one descriptor which reflects a relatively poor correction between the descriptor and the soil structure (in situ soil profile structure description) is considered to be a poor indicator of the collapsible soil structure due to erroneous or poor in situ soil structure observations resulting from unfavourable local conditions namely dry, dusty soil conditions and very brief intact standup time of test pit side walls.

Collapsible soil structure, Loopeng, transported soil, empirical properties comparison.

Funding: Council for Geoscience (of South Africa):

Department of Cooperative Governance, Human Settlements and Traditional Affairs Northern Cape, South Africa (COGHSTA).

Conflicts of interest/Competing interests: Not applicable

Availability of data and material: Subject to consent by Department of Cooperative Governance, Human Settlements and Traditional Affairs Northern Cape, South Africa (COGHSTA).

Code availability: Not applicable

Authors' contributions: Not applicable - one author only. 


\section{Introduction:}

During 2019 the Council for Geoscience conducted a geotechnical investigation at Loopeng Village and surrounds, located in the Northern Cape Province of South Africa, to determine the near surface founding properties on the site with the view to formal suburban development of a number of existing informal rural villages (Stapelberg et al. 2020). The site is roughly 2000 hectares in extent, elongated and located along the course of the episodic Moshaweng River, roughly 80 kilometres northwest of the town of Kuruman.

\section{Geological setting}

Reference to the regional geological map for the area [the 1:250 000 Geological Map Sheet 2622 Morokweng, Council for Geoscience (2007)] indicates that the region and vast majority of the site is covered by aeolian sand of the Gordonia Formation (Fm) (of the Kalahari Group) and that small outcrops of gravelly calcrete/sandy limestone and sandstone/siltstone of respectively the Mokalanen and Eden Formations (both Formations belonging to the Kalahari Group) occur over small portions of, and in close proximity to the site (Figure 1). Additionally, during the investigation, areas of rock outcrop and semi-consolidated regolith material (all too localized to indicate on the regional scale geological map) were encountered. These include mudstone of the Budin Formation, diatomaceous earth weathering to sandy silt or silty clay (Lonely Formation), gravelly sand (Obobogorop Formation), alluvial sandy silt (mainly in low-lying areas near the river) and hillwash (silty sand often containing a gravel component). Most of the soil horizons have been partially calcretized - generally to powdery calcrete or calcareous soil, but in parts so well developed (nodular to hardpan calcrete varieties) that this younger calcrete is difficult to distinguish from the pre-existing residually weathered Mokalanen Formation calcrete/sandy limestone. The area is known to be dolomitic (with dolomite bedrock occurring at less than 100 metres depth below cover materials). However, this particular study focused on investigating the near-surface geology and regolith materials - the dolomitic stability was investigated in a separate study through percussion drilling (Mankayi 2019).

Fig. 1 Site location and geology (from Stapelberg et al. 2020)

\section{Details of investigation}

In order to properly investigate the engineering properties of the regolith materials whilst adhering to the South African National Standard (SANS:634 2012) recommendations for this size of residential development, the following procedures were inter alia performed:

- Profiling of 589 randomly distributed test pits, dug with the use of a tractor loader backhoe (TLB) to a depth of 3 metres or refusal.

- Conducting of grading analyses and Atterberg Limit tests (53 in total) to determine basic properties of the soil horizons.

- Oedometer testing of undisturbed samples ( 9 in total) to determine collapse potential of the sandy soil horizons.

\section{$\underline{\text { Aim of this study }}$}

Since it is well documented that aeolian sands and particularly those of the Gordonia Formation (part of the Kalahari Group) are prone to collapse settlement (Schwartz and Yates 1980; Brink et al. 1982; Brink 1985) and it was known before undertaking the investigation that the site is extensively covered by Kalahari Group (aeolian) 
sand, it was considered a perfect opportunity to investigate whether the expected collapsing sand structure is indeed present in the aeolian materials on site and determine how well the collapse structure is developed. Furthermore, since the site envelops the Moshaweng River, and abundant alluvial silty sand (potentially collapsing) occurs in low lying areas on the river banks, a secondary aim was to similarly investigate the possible existence of a collapsing sand soil structure for the fine alluvium. Additionally, it was considered prudent to investigate to what extent empirical soil properties are indicative of the presence of a collapsing sand structure.

\section{$\underline{\text { Assessment }}$}

\section{$\underline{\text { Oedometer test results }}$}

The CP [collapse potential of oedometer tested samples inundated at $200 \mathrm{kPa}$ pressure as originally defined by Jennings and Knight (1975)] values vary between 4,5\% and 10,3\% and it is clear that collapse potentials of both the aeolian and fine alluvial horizons are substantial and cannot be ignored were the horizons to act as foundation horizons for fixed structures or infra-structure elements. In terms of the Jennings and Knight's fivefold classification (see Table 1 below) the soils should on average be considered as "trouble" in the context of erection of structures. [The results of the collapse potential (CP) tests are summarized in Table 2].

\section{TABLE 1: Collapse potential severity classification in context of the erection of structures (Jennings and Knight 1975)}

\begin{tabular}{|c|l|}
\hline Collapse potential (CP) & Severity of problem \\
\hline $0 \%-1 \%$ & No problem \\
\hline $1 \%-5 \%$ & Moderate trouble \\
\hline $5 \%-10 \%$ & Trouble \\
\hline $10 \%-20 \%$ & Severe trouble \\
\hline$>20 \%$ & Very severe \\
\hline
\end{tabular}

Considering the thickness of the soil horizons (mostly in excess of 1,5 metres and often in excess of 3,0 metres), it is clear that engineering solutions are required in order to stabilize foundation horizons for the purpose of construction. Foundation solutions pertaining to soils with a collapse structure which have been considered by inter alia Schwartz (1985) and Gildenhuys (2010) depend on the type and size of structure, as well as the collapsible horizon thickness and generally involves one of five different strategies namely:

1) Avoidance of the triggering mechanism (preventing moisture content increase)

2) Chemical stabilization

3) Piled and pier foundations

4) Design of structures to accommodate the quantified collapse

5) Any one of a variety of densification techniques to the collapsible horizon

Since solutions to the collapse problem is not the aim of this study, no further elaboration on these techniques is deemed necessary here and interested readers are referred to the above mentioned publications.

\section{Aspects apart from oedometer tests suggesting existence of a collapsible soil structure}


Various field and laboratory criteria apart from oedometer or tri-axial testing have been suggested for indicating or predicting the presence of a collapsing sand structure (Schwartz 1985; Rust et al. 2008). These inter alia include the following:

1) Soils for which an open (pinholed) soil structure is observed in profile.

2) Soils which are poorly graded (uniform) - i.e having grain size distribution curves comparable to those determined by either Knight (1961) or Errera (1977).

3) Silty sands or fine sands - i.e soils which typically classify as "sand with silt", "silty sand", "fine sand" or "sand with silt fines" in the Unified (ASTM) or AASHTO soil classification systems.

4) Materials (poorly graded sand-silt mixtures) containing a low clay content (of 3 to $25 \%$ ).

5) Low density soils (even though they may have high consistency) - dry densities of less than $1600 \mathrm{~kg} / \mathrm{m}^{3}$ probably suggesting a collapsing soil structure.

6) Soils with high void ratios.

\section{Soil structure in profile}

Sandy to silty soil mixtures with low clay content in general exhibit little soil structure in profile - apart from where a pinhole structure is developed. This also holds true on this site - with structure (fissuring, shattering and slickensiding) limited to residual/completely weathered clay or mudstone soil horizons. The sandy, silty sand or sandy silt horizons (aeolian, alluvium and hillwash soils) exhibit either "pinhole" or "intact" soil structures, with roughly equal numbers having "pinhole" and "intact" structure descriptions.

Reference to the soil structure descriptors in the data set presented in Table 2 (see row headed "Material description in profile") indicates that indeed, for the 10 profile horizons from which undisturbed samples have been collected, this rough percentage holds true, with 50\% having a "poorly pinholed" soil structure (the balance being "intact"). The fact that all nine of the samples that could be oedometer tested (one sample crumbled and fell apart prior to testing) have collapse potential values of moderate to high significance $(4,5-10,3 \%$ collapse potential at $200 \mathrm{kPa}$ pressure), indicates that observation of a "pinhole" soil structure in profile is a relatively poor indicator of collapse potential (one would have expected a higher percentage of "pinhole" soil structure descriptions to assume a good correlation between soil structure description and a collapse structure).

However, the following factors may have led to lower numbers of "pinhole" soil structures being identified in profile than what is actually present in situ:

- The collapsing soil horizons all have low clay contents (all less than 10\%, and on average 5-6\%) and were all dry, (reflecting moisture contents of $5,2 \%$ or in less in laboratory tests). This meant that very little cohesive or apparent cohesive forces which could have assisted in keeping test pit sidewalls stable were present. Hence, test pit sidewalls often experienced partial collapse or sliding during profiling - destroying the intact structure and thus also the pinholes where they were present.

- Calcrete is widespread throughout the site and particularly powdery calcrete horizons occur in the vast majority of test pits. This, together with the fact that the soils were dry, meant that dusty conditions prevailed during test pit digging. Settling dust particles on pit sidewalls meant that the intact soil structure was often obscured and couldn't be properly observed throughout the entire soil horizon.

The solution to the two problems posed above was to open a few small areas here and there in the particular soil horizon with the aid of a geological pick in order to gain access to and observe the intact and clean (of dust) soil structure. It is well known though that pinholes in a soil horizon with a collapsing sand structure generally do not occur evenly distributed throughout the entire horizon - but rather in clumps. Hence, the practice of looking for pinholes here and there in a horizon is not fail-safe since areas of pinholing may be missed altogether - which is probably what happened in many test pits on this site. It needs to also be noted that the pinholing structure itself was often described as "poorly pinholed" - i.e. the pinholes themselves often were not developed throughout the area of observation. 


\section{Grading curve comparisons}

Grading analyses were performed on samples from 14 aeolian and 5 fine alluvium soil horizon locations. Comparison of the grading curves with two existing typical grading curve envelopes are shown in Figures 2 a and $2 \mathrm{~b}$. The following aspects are apparent:

1) For the aeolian samples (Figure 2a):

Apart from slight overabundance at the coarse end of the spectrum for roughly half of the samples, the grading curves of the aeolian material fall overwhelmingly within the Errera envelope suggested for typical collapsing sands (Errera 1977).

- The clay $(<0,002 \mathrm{~mm}$ diameter) content of samples is generally low but for all samples lie in the range between 2 and $8 \%$ and thus within the Errera envelope for this grain size.

- The roughly $10 \%$ gravel sized fragment exhibited by one sample is a rarity - the gravel component was brought about by local pedogenic ferruginization (nodular ferricrete) of a sub-horizon near the base of the aeolian horizon.

Fig. 2a Grading curve fit for aeolian sands (envelopes after Errera 1977; Knight 1961)

2) For the fine alluvium samples (Figure 2b):

- The grading curves largely mimic those of the aeolian samples with however generally a slight increase in the percentage of silt sized $(0,002-0,075 \mathrm{~mm}$ diameter) particles. Although these grading curves also largely lie within the Errera envelope, their shape to a large extent duplicate the shape of the envelope for collapsing sand as defined by Knight (1961).

- The fraction of clay-sized particles (ranging between 2 and 10\%) is close to that of the aeolian material.

Even though the samples are called "fine alluvium" (and were thus not collected from those alluvium horizons containing largely gravel to cobble sized material) there is a roughly similar (to that of the aeolian materials) percentage at the top end of the grain size distribution curve where there is a slight overabundance of coarse grained material - thus lying outside both the distribution envelopes for typical collapsing sands. This coarse grain component is largely the effect of the inclusion of trace amounts of small calcrete nodules. The one sample containing $(0-2 \%)$ grains of $5-20 \mathrm{~mm}$ represents a sub-horizon containing rounded alluvial pebbles (i.e. a mixture of mostly fine and minor slightly coarser alluvium).

\section{Fig. 2b Grading curve fit for fine alluvium (envelopes after Errera 1977; Knight 1961)}

\section{Soil classes}

Since both the aeolian and alluvial soils have very low clay fractions, both materials are non-plastic and Atterberg values don't contribute to the soil classifications over and above what is suggested by the grading analyses curves.

1) Unified System (ASTM 1999):

- As can be seen in the soil class names mentioned in Table 2, (and also suggested by the grading curves), the classification for the Unified System suggests a slight increase in finer grained material for the alluvial material in comparison to that of the aeolian material. The aeolian samples mostly classify as (poorly graded) sand with silt and to a lesser extent as silty sand (i.e, having lesser silt content), whereas for the alluvial material the opposite applies - i.e. the material mostly classifies as silty sand and to a lesser extent as sand with silt (i.e. fewer samples having relatively high sand content in comparison to the aeolian material).

- One of the 14 aeolian samples classifies as well-graded sand (with silt). This is surprising since a collapsing sand soil structure is generally associated with poorly graded sand (not with well graded sand). 
2) AASHTO System (AASHTO 1982):

- This system classifies both the aeolian and alluvial materials mostly as sand with (low plasticity) silt fines. However, it also classifies a substantial portion of the aeolian samples as fine sands, whereas for the alluvial material one sample classifies as (low compressibility) silt. So, it is also for this classification system true that the alluvial material in general classifies as slightly finer grained in comparison to aeolian material.

Although particular soil classes per se are not associated with a collapsing soil structure, research have in the past indicted that collapsing sands generally classify as poorly graded (uniform) fine sands or sand-silt mixtures with a minor clay component. The class names stated here above (sand with silt/silty sand/fine sand/silt) thus merely support the conclusion drawn from the grading curves - which suggest that, based on grain size distribution, a collapsing sand structure is present in both the aeolian and alluvial materials.

\section{4. $\underline{\text { Clay content }}$}

Clay content of materials on its own doesn't necessarily suggest the existence of a potential collapse soil structure. However, due to the inherent "open" soil structure required for collapse, it stands to reason that poorly graded siltsand mixtures either devoid of clay fraction materials or on the other hand with too large a clay component are unlikely to possess a collapsible structure. A small fraction of clay is required as "bridging" material between sand/silt grains, but if the clay fraction is too high, it tends to fill the voids between larger grains - thus preventing the forming of an open, collapsible void structure. Handy (1973) suggests that soil with a clay fraction of less than $16 \%$ has a "high probability of collapse", whereas the grading curves mentioned in chapter 2 indicate clay percentages in the range $2-25 \%$ for collapsing sands. The tabled (Table 2$)$ clay contents $(2-8 \%$ for aeolian material and $2-10 \%$ for alluvial material) lie within the bottom half of this suggested clay content band for typical collapsing sands. This indicates that a collapsible structure is probable for both the aeolian and fine alluvial soils on site.

\section{Soil density}

Organic soils or unconsolidated soils generally are of low density and a low soil density on its own thus does not necessarily indicate a collapsing soil structure. Brink (1985) however, cite, with reference to aeolian deposits, from a correlation curve between dry density and collapse potential, a dry density of $1600 \mathrm{~kg} / \mathrm{m}^{3}$ as figure above which very limited data is available indicating a collapsible structure. He furthermore indicates $1670 \mathrm{~kg} / \mathrm{m}^{3}$ as the maximum dry density for which collapse is possible for aeolian material. Rust et al. (2005) indicate the occurrence of a collapsing sand structure in aeolian soils on the Mozambique coast with average dry density of $1650 \mathrm{~kg} / \mathrm{m}^{3}$. The aeolian and alluvial soils on the Loopeng site do not have high not organic content and furthermore, although mostly loose to very loose, often have medium dense (to even dense in a few instances) consistency descriptions. Medium dense to dense consistency descriptions indicate dry densities in excess of $1600 \mathrm{~kg} / \mathrm{m}^{3}\left(>1750 \mathrm{~kg} / \mathrm{m}^{3}\right.$ for dense soils).

The nine laboratory determined dry densities are, regardless of their respective consistency descriptions, less than $1600 \mathrm{~kg} / \mathrm{m}^{3}$ (with the exception of one which is slightly denser at $1630 \mathrm{~kg} / \mathrm{m}^{3}$ ). It is thus clear that these low dry densities are in general the result of high void ratios as would be expected for a collapsible soil structure. The results for this study show that the dry density values suggested by Brink $\left(1600 \mathrm{~kg} / \mathrm{m}^{3}\right.$ or less in general and up to a maximum of $1670 \mathrm{~kg} / \mathrm{m}^{3}$ ) can also applied to aeolian soils in the Loopeng area to indicate the presence of collapsible soils. Furthermore, these values are similarly applicable to the fine alluvial soils of the area.

\section{Void ratios}

As can be expected of (largely) quarzitic sands, the low soil densities discussed here above would suggest high void ratios - which was indeed found to be the case for these soils, with tested void ratios varying between 0,62 and 0,77 ( 0,68 on average). 
One needs to realize that taking of undisturbed samples and preserving of their intact structure to allow laboratory testing of the void ratio is difficult to attain for non-cohesive soils. Samples often break apart or crumble during either sampling or transportation to the laboratory - particularly in case of soil with a loose or very loose consistency and low moisture content. (On the other hand, to cut a truly undisturbed sample from a dense to very dense soil is very difficult due to the shear strength of the soil, which makes it nearly impossible to cut a block with hand tools or a spade. If power tools are used to dig out a block, one always suspects the structure to not be truly undisturbed). Due to these factors, oedometer testing is often not undertaken and intact void ratio data for non-cohesive soils not readily available. Hence, using of soil void ratio magnitudes to predict a collapsible soil structure is impractical and not generally used for predictive purposes. However, since void ratios are determined when undertaking oedometer testing, this particular data set for this study is available for comparative purposes by later researchers.

\section{$\underline{\text { Conclusions }}$}

1. The oedometer tests confirm that both the aeolian and the fine alluvium soils in the Loopeng area process collapsible soil structures.

2. Although a weak correlation exists between observation of a pinholed soil structure in test pits and laboratory determined collapse potentials, the pinhole soil structure in the dry, non-cohesive transported soil horizons on this site is often obscured and thus incorrectly described as "intact" - i.e. not presenting with pinholes. More precise soil structure observation may well increase correlation between occurrence of pinholes and the collapsible soil structure.

3. Both the grading curves and the clay percentages of the aeolian and fine alluvial soil horizons conform to the normal shapes and values associated with a collapsible soil structure as observed in existing studies. This indicates that these soils are likely to have collapsible structures - as the oedometer (collapse potential) testing confirms. The curves additionally indicate that the fine alluvium is slightly finer grained than the aeolian soil.

4. The soil classes, determined with conventional geotechnical soil classification systems, indicate that the soils are generally uniformly graded sand-silt mixtures with minor clay content, as would be expected for the majority of collapsible soils.

5. Both low dry densities and high void ratios indicate that the aeolian and fine alluvial soils most probably possess collapsible soil structures.

\section{Consent to Publish}

1. Consent to publish this article using data generated during the field work and laboratory testing was given by COGHSTA (see attached letter).

2. Consent to publish this article from research results obtained and reporting on the Loopeng area investigation was given by Council for Geoscience. (see attached letter).

\section{$\underline{\text { References }}$}

AASHTO, 1982. See American Association...

ASTM, 1999. See American Society...

American Association of State Highway and Transportation Officials, 1982. AASHTO Materials, Part I, Specifications, Washington, D.C.

American Society for Testing and Materials, 1999. Annual book of ASTM Standards, Sec. 4, Vol. 04.08, West

Conshohocken, Pa. 
Brink ABA., 1985. Engineering Geology of South Africa, Vol. 4, Chapter 6: Aeolian deposits of the Interior, Building Publications, Silverton.

Brink ABA, Partridge TC, and Williams AAB, 1982. Soil survey for engineering. Clarendon Press, Oford, pp. 118-124.

Council for Geoscience, 1: 250000 Geological Map sheet 2622 Morokweng, 2007.

Errera LA, 1977. Stress paths and collapsing soils. MSc. thesis, Civil Engineering Department, University of Cape Town.

Handy RL, 1973. Collapsible soils in Iowa. Soil Science Society of America Proceedings, Vol. 37, pp. $281-284$.

Gildenhuys N, 2010. The occurrence and extent of collapse settlement in residual granite in the Stellenbosch area. MSc. Eng. Thesis, University of Stellenbosch, 178 pp.

Jennings JE and Knight K, 1975. A Guide to Construction on or with materials exhibiting additional settlement due to "collapse" of grain structure. Proceedings, Sixth Regional Conference for Africa on Soil Mechanics and Foundation Engineering, Durban. Volume 1, pp. 99-105.

Knight K, 1961. The collapse of structure of sandy sub-soils on wetting. PhD- thesis, Department of Civil Engineering, Cape Town University, 95 pp.

Mankayi N, 2019. Geotechnical Investigation - Preliminary dolomite stability studies for Loopeng and the surrounding villages, Joe Morolong Local Municipality, Northern Cape, Council for Geoscience Report 2019-0197, December.

Rust E, Heyman G and Jones G, 2005. Collapse potential of partly saturated sandy soils from Mozal, Mozambique, Journal of the South African Institution of Civil Engineering, Vol 47, No 1, pp. 8-14.

Rust E, Heyman G, and Jones G, 2008. Collapse soils: An overview. Joint SAICE/SAIEG seminar on problem soils in South Africa, 3-8 Nov. 2008, pp. 47-56.

SANS:634, 2012 (Edition 1). South African National Standard. Geotechnical Investigations for Township Development. SABS Standards Division, Pretoria, ISBN 978-0-626-27636-2, 18 pp.

Schwartz K, 1985. Problem soils in South Africa: Collapsible soils, The Civil Engineer in South Africa, pp. 378391.

Schwartz K and Yates JRC, 1980. Engineering properties of aeolian Kalahari sands. Proceedings of the $7^{\text {th }}$ Regional Conference for Africa on Soil Mechanics and Foundation Engineering, Accra.

Stapelberg FDJ, Munyai D, and Mankayi N, 2020. Near surface geotechnical investigation report for Loopeng Village and surrounds, Joe Morolong Local Municipality, Northern Cape Province. Council for Geoscience report 2017-0050, 42 pp. 
TABLE 2: Summation of field descriptions and laboratory test results

\begin{tabular}{|c|c|c|c|c|c|c|c|c|c|c|}
\hline Sample & $\begin{array}{c}\text { TP8 } \\
\text { a } 0,9 \mathrm{~m}\end{array}$ & $\begin{array}{c}\text { TP54 } \\
\text { (a. } \mathbf{0 , 5 5 m} \\
\end{array}$ & $\begin{array}{l}\text { TP108 } \\
\text { a } 0,5 \mathrm{~m} \\
\end{array}$ & $\begin{array}{l}\text { TP160 } \\
\text { a } 0,7 \mathrm{~m}\end{array}$ & $\begin{array}{c}\text { TP193 } \\
\text { a } \mathbf{0 , 4 5 ~ m} \\
\end{array}$ & $\begin{array}{c}\text { TP478 } \\
\text { a } \mathbf{0 , 7 5 m} \\
\end{array}$ & $\begin{array}{c}\text { TP527 } \\
\text { (a. } \mathbf{0 , 8 5 m}\end{array}$ & $\begin{array}{r}\text { TP327 } \\
\text { a, } \mathbf{0 , 8 m} \\
\end{array}$ & $\begin{array}{r}\text { TP354 } \\
\text { a } 0,4 \mathrm{~m} \\
\end{array}$ & $\begin{array}{l}\text { TP523 } \\
\text { (a) } 0,8 \mathrm{~m} \\
\end{array}$ \\
\hline \multicolumn{11}{|c|}{ Soil profile description data } \\
\hline Material origin & $\begin{array}{l}\text { Aeolian } \\
\text { (slightly } \\
\text { calcretized) }\end{array}$ & Aeolian & $\begin{array}{l}\text { Aeolian } \\
\text { (slightly } \\
\text { calcretized) }\end{array}$ & Aeolian & Aeolian & $\begin{array}{l}\text { Aeolian } \\
\text { (slightly } \\
\text { calcretized) }\end{array}$ & Aeolian & $\begin{array}{l}\text { Alluvium } \\
\text { (slightly } \\
\text { calcretized) }\end{array}$ & $\begin{array}{l}\text { Alluvium } \\
\text { (slightly } \\
\text { calcretized) }\end{array}$ & Alluvium \\
\hline $\begin{array}{l}\text { Horizon depth } \\
\text { (m) }\end{array}$ & $0->2,9$ & $0,3-0,9$ & $0-1,8$ & $0,3-1,8$ & $0,4-1,4$ & $0,2-1,5$ & $0,3-1,4$ & $0,2-1,4$ & $0-0,8$ & $0,3-1,7$ \\
\hline $\begin{array}{l}\text { Material } \\
\text { description in } \\
\text { profile }\end{array}$ & $\begin{array}{l}\text { Light red, } \\
\text { loose, intact, } \\
\text { silty sand. }\end{array}$ & $\begin{array}{l}\text { Light red } \\
\text { speckled } \\
\text { dark grey, } \\
\text { medium } \\
\text { dense, } \\
\text { intact, silty } \\
\text { sand. }\end{array}$ & $\begin{array}{l}\text { Light red } \\
\text { faintly } \\
\text { mottled dark } \\
\text { yellow, } \\
\text { loose, poorly } \\
\text { pinholed, } \\
\text { silty sand. }\end{array}$ & $\begin{array}{l}\text { Light red, } \\
\text { medium } \\
\text { dense, } \\
\text { poorly } \\
\text { pinholed, } \\
\text { silty sand. }\end{array}$ & $\begin{array}{l}\text { Light red, } \\
\text { loose, } \\
\text { poorly } \\
\text { pinholed, } \\
\text { silty sand. }\end{array}$ & $\begin{array}{l}\text { Light orange } \\
\text { brownish } \\
\text { mottled off- } \\
\text { white and } \\
\text { black, medium } \\
\text { dense, intact, } \\
\text { silty sand. }\end{array}$ & $\begin{array}{l}\text { Light } \\
\text { orange to } \\
\text { brownish, } \\
\text { medium } \\
\text { dense, } \\
\text { intact, silty } \\
\text { sand. }\end{array}$ & $\begin{array}{l}\text { Light brown } \\
\text { speckled off- } \\
\text { white and light } \\
\text { grey, medium } \\
\text { dense, poorly } \\
\text { pinholed, sandy } \\
\text { silt with traces } \\
\text { of fine gravel. }\end{array}$ & $\begin{array}{l}\text { Light yellowish } \\
\text { orange speckled } \\
\text { white, medium } \\
\text { dense, poorly } \\
\text { pinholed, sandy } \\
\text { silt with traces of } \\
\text { gravel. }\end{array}$ & $\begin{array}{l}\text { Dark } \\
\text { brown, } \\
\text { loose to } \\
\text { medium } \\
\text { dense, } \\
\text { intact, silty } \\
\text { sand. }\end{array}$ \\
\hline \multicolumn{11}{|c|}{ Oedometer test data } \\
\hline CP (\%) & 4,5 & 8,3 & 6,0 & 7,3 & 6,2 & 9,4 & 8,6 & $\mathbf{1 0 , 3}$ & \multirow{4}{*}{$\begin{array}{l}\text { None (sample } \\
\text { disintegrated } \\
\text { during transport) }\end{array}$} & 5,7 \\
\hline $\begin{array}{l}\text { Dry density } \\
\left(\mathrm{kg} / \mathrm{m}^{3}\right)\end{array}$ & 1570 & 1550 & 1550 & 1560 & 1530 & 1580 & 1580 & 1480 & & 1630 \\
\hline Void ratio & 0,68 & 0,71 & 0,69 & 0,70 & 0,70 & 0,64 & 0,64 & 0,77 & & 0,62 \\
\hline $\begin{array}{l}\text { Natural } \\
\text { Moisture } \\
\text { content }(\%)\end{array}$ & 1,6 & 1,5 & 3,3 & 3,2 & 1,5 & 1,9 & 2,8 & 5,2 & & 1,6 \\
\hline \multicolumn{11}{|c|}{ Grading analyses tests } \\
\hline & \multicolumn{5}{|c|}{ Aeolian (14 samples tested) } & \multicolumn{5}{|c|}{ Alluvium (5 samples tested) } \\
\hline & \multicolumn{4}{|l|}{ Name } & No. & \multicolumn{4}{|l|}{ Name } & No. \\
\hline Unified Class & \multicolumn{4}{|c|}{$\begin{array}{l}\text { Poorly graded sand with silt (SP-SM) } \\
\text { Silty sand (SM) } \\
\text { Well graded sand with silt (SW-SM) }\end{array}$} & $\begin{array}{l}9 \\
4 \\
1\end{array}$ & \multicolumn{4}{|c|}{$\begin{array}{l}\text { Silty sand (SM) } \\
\text { Poorly graded sand with silt (SP-SM) }\end{array}$} & $\begin{array}{l}4 \\
1\end{array}$ \\
\hline AASHTO Class & \multicolumn{4}{|c|}{$\begin{array}{l}\text { Sand with low plasticity silt fines (A.2.4) } \\
\text { Fine sands (A3) }\end{array}$} & $\begin{array}{l}9 \\
5\end{array}$ & \multicolumn{4}{|c|}{$\begin{array}{l}\text { Sand with low plasticity silt fines (A.2.4) } \\
\text { Low compressibility silts (A4) }\end{array}$} & $\begin{array}{l}4 \\
1\end{array}$ \\
\hline Clay content & \multicolumn{5}{|c|}{$\begin{array}{l}\text { Range: } 2-8 \% \\
\text { Average: } 4,8 \%\end{array}$} & \multicolumn{5}{|c|}{$\begin{array}{l}\text { Range: } 2-10 \% . \\
\text { Average: } 6,0 \% .\end{array}$} \\
\hline
\end{tabular}




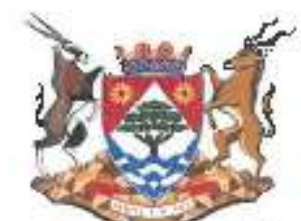

Enquilles : Mtr \&. Dienkikates

Reference : L.1.2 S.P

280 Pretoria Strant

Silverton Pretoria

Private Bag $\times 112$

Pretorla 0001

\section{Attentlon: Mr hosa Mabuza}

RE: REQUEST FOR PERMISSION TO USE GEOSCIENTIFIC DATA COLLECTED FOR COOPERATIVE GOVERNANCE HUMAN SETTLEMENTS AND TRADITIONAL AFFAIRS (COGHSTA) NORTHERN CAPE PROVINCE IN A COUNCIL FOR GEOSCIENCE (CGS) \$TATUTORY PROJECT.

Wre have no objections to the CGS using the gexscientific data collected for COGHSTA. Northern Cape Prownce In its ataiutoy projects and research publications programmes. As these by-products of gecociantific data will provide all of LS with a better understanding on Northern Cape's geological getting and characteristics which are vital in our housing felinery endeavours.

W't would like to request that CGS shares with COGHSTA all of its relevant research flnd ngs that fall within Northern Cape as and when they become arailable.
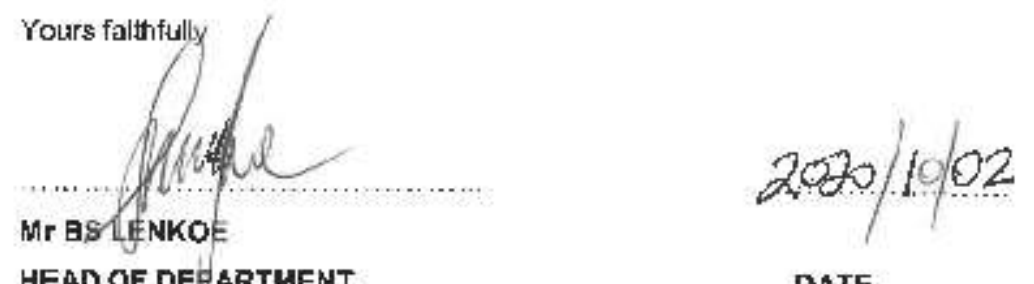

HEAD OF DEHARTHENT 


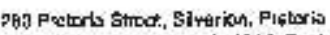

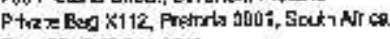

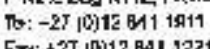

$F a x+2 T$ DDT12 RAI 1221

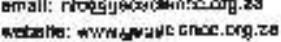

Council for Geosclence

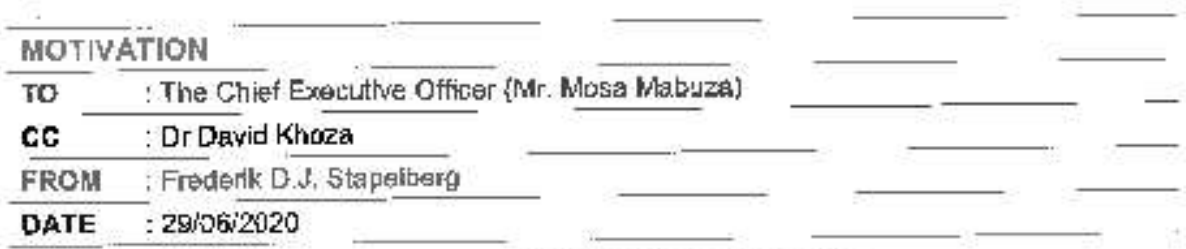

RE: MOTIVATION FOR PUBLICATION IN A SCIENTIFIC JOURNAL

\section{Background and Deliberations}

Sir,

During work on a rccent CGS commercial project undertaken for the Department of Coopergte Durng work dn a recent CSS commel Trantional Affalrs (COGHSTA) Northern Cape - The nearGovernance, Human Settements and Tradltional Affalrs (COGHSTA) Northern Cape- No nearsurface geotechnical Inwestigation for Loopeng Village and Surrounds, CGS project No. CO-20195821 PHASE 30\}, some darta came to fight which L judge as worthy of invesligeting with the vlew of publishing an article In a peer reviewerd

traneported deposits oce

The costs for the above-menlioned are as fo.lows:
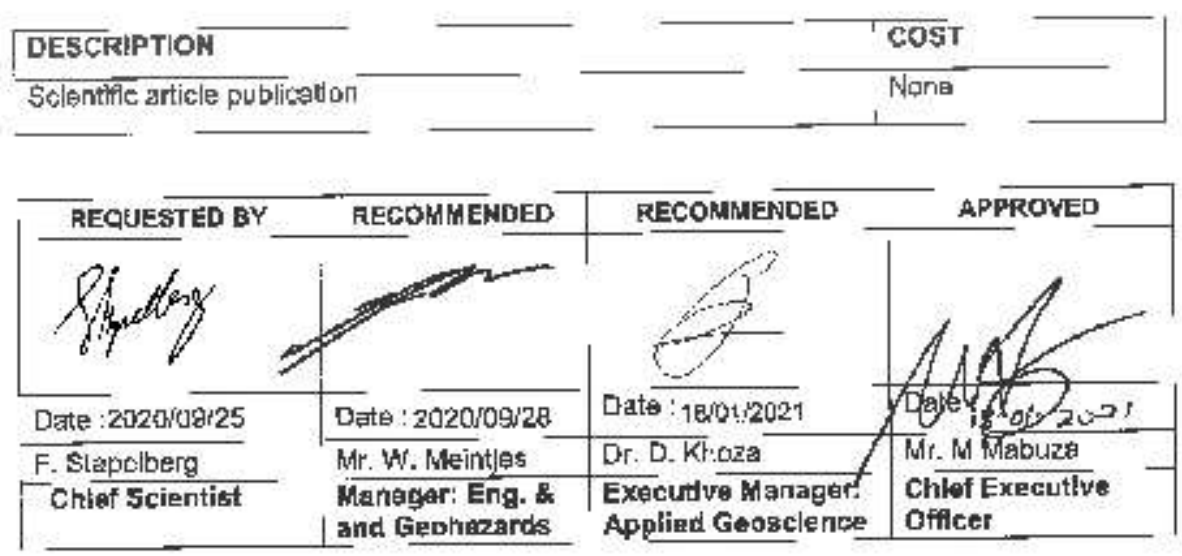
Figures

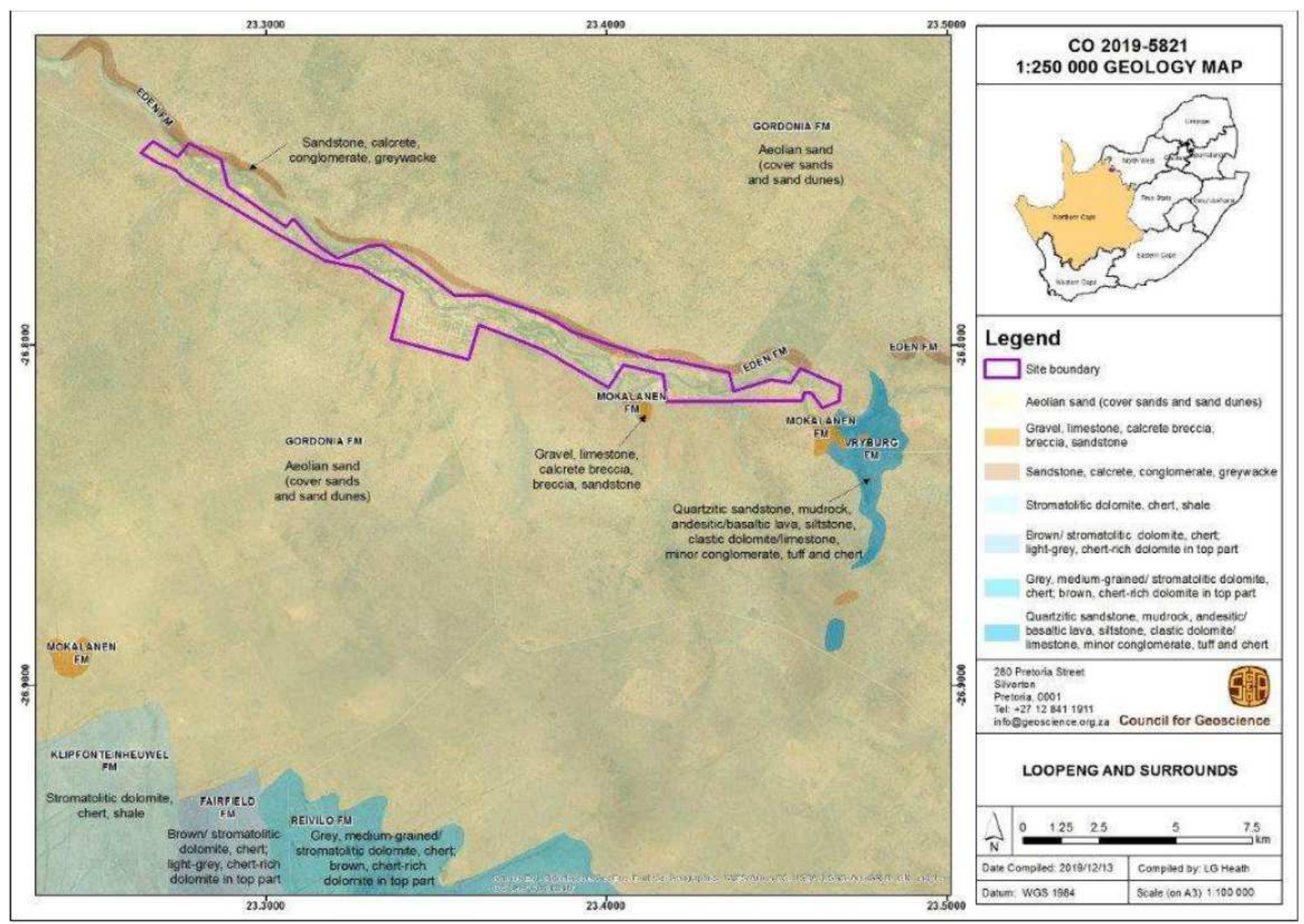

\section{Figure 1}

Site location and geology (from Stapelberg et al. 2020)
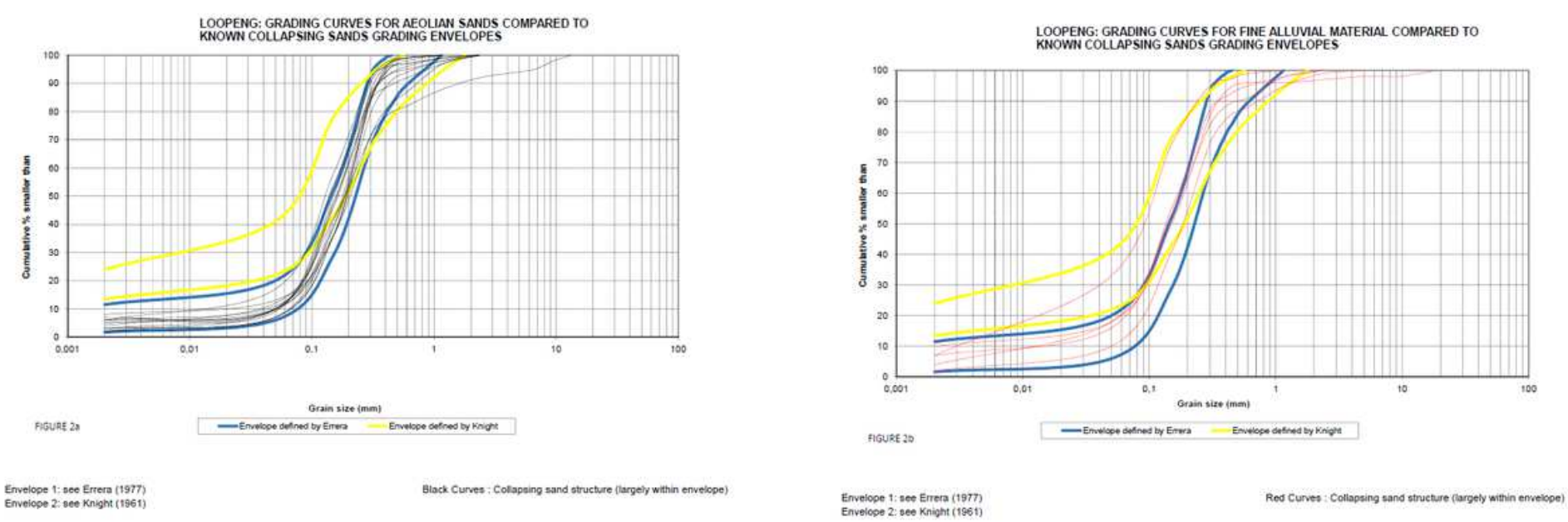
a Grading curve fit for aeolian sands (envelopes after Errera 1977; Knight 1961) b Grading curve fit for fine alluvium (envelopes after Errera 1977; Knight 1961) 